\title{
A QUICK COMPARISON OF PATROL EFFORTS FOR SUPPORTIVE PROTECTION: A CASE STUDY OF TWO STATIONS IN VIETNAM
}

\author{
DONG, L. K. $.^{1,2,3^{*}}-$ SutineE, S. ${ }^{1,4}-$ HOA, A. X. ${ }^{1}$ - DONG, N. P. ${ }^{3}$ - Ali, S. ${ }^{1}-$ MANOP, P. ${ }^{5}-$ \\ KUAANAN, $\mathrm{T}^{1 *}$ \\ ${ }^{1}$ Faculty of Environmental Management, Princes of Songkla University \\ Hat Yai 90110, Thailand \\ ${ }^{2}$ People's Committee of Thanh Hoa Province, 440000, Vietnam \\ ${ }^{3}$ Department of Agricultural and Rural Development, Thanh Hoa Province 440000, Vietnam \\ ${ }^{4}$ Coastal Oceanography and Climate Change Cluster, Princes of Songkla University \\ Hat Yai 90110, Thailand \\ ${ }^{5}$ Faculty of Law, Princes of Songkla University, Hat Yai 90110, Thailand \\ *Corresponding authors \\ e-mail: Ledongthph@gmail.com (L.K. Dong); uhugua@hotmail.com (T. Kuaanan) \\ phone: $+84-985-517-789$ \\ (Received $16^{\text {th }}$ Dec 2017; accepted $27^{\text {th }}$ Feb 2018)
}

\begin{abstract}
Law enforcement efforts related to patrol routes may be sufficiently supporting forest protection around the world. However, the adequacy of patrol efforts of stable patrol routes, with regard to illegal activities on conservation at the local level, has infrequently been explored in the past time. This study is to compare the highest qualification of current threats to conservation in protected areas (PAs) of both Nam Tien and Hon Can forest stations (FSs) which belongs to Pu Hu and Xuan Lien Nature Reserves (NRs). A total of eleven-track was explored using a conventional patrol performance. Typically, forest rangers have established the permanent GPS-tracks through the areas with the highest potential of negative effects of conservation in the sub-area forest because of recording and preventing effective illegal activities. As a result, patrol-hours of patrolling routes in both sides were correlated to illegal activity encounters and the number of staff. In contrast, the number of illegal activity in Nam Tien FS was correlated with patrol-distance. It is concluded that forest management should not only consider on the number of staff, but also patrol-hours could be one of a specific indicator of working field in the shortterm period of adaptive patrol in the sustainable conservation.
\end{abstract}

Keywords: law enforcement effort, conservation, forest, illegal activity, patrol routes

\section{Introduction}

Forest, as the largest natural benefit, plays an essential role in the activities of global conservation (Kusters and Belcher, 2004; Bach et al., 2005; Queiroz et al., 2013; Zhou, 2015; Patarkalashvili, 2016a). Due to cattle grazing, logging, and poaching, that have been declining biodiversity (Struhsaker, 1997; He et al., 2009; Critchlow et al., 2016) by strengthened human preferences and human inefficiencies of collecting resources acquisition. Usually, there are several stakeholders in local areas with often have the conflict of interests in forest management. It should be noted that residents commonly gather fuelwood and timber illegally, as well as other NTFPs (Allendorf et al., 2007a). And the protective function hugely depends on the small-scale local situation (Teich and Bebi, 2009). Consequently, it has been affecting forest protection, especially in the 
protected forest where the NRs resides (Araújo, 2003; Liang et al., 2011; Fuentes, 2011). These issues get more complexes when disturbances to forest functioning and management have been shown off (Rist and Moen, 2013; Zhou, 2015).

The key to conservation and protection of species and their natural habitat is to reduce human activities in such PAs that significantly play an outstanding role in biodiversity conservation (Stoll-Kleemann, 2010; Patarkalashvili, 2016) and request the observation and prevention of its (Young, 2017). To protect biodiversity effectively, PAs, as nature reserves and national parks in Vietnam, have been established (Bleher et al., 2006; Isbell et al., 2011; Ciccarese et al., 2012; Clark et al., 2013; Geldmann et al., 2013). Conservation strategy in the PAs has been improving protection which involves stakeholders like local communities, the government authorities, and international organizations (Thi et al., 2017). And, noncompliance with regulations is often the rule from government or location areas, rather than reality, illegal activity and others of forest resource requirement grow continues (Arias, 2015). Particularly, to enhance management protection, a simple instrument is required for an assessment of human activity (Bleher et al., 2006).

In all sub-stations from NRs, as special-use forest areas, forest rangers are greatly responsible for the protective action of a certain area where local people frequently have to change their behavior, as natural resources they were formerly using maybe come off-limits (Stevens, 1997). Local managers of NRs may apply for specific regulations of inside core-zone more strictly than outside forest protection. For example, whilst no activity extraction is allowed by law (Albers and Grinspoon, 1997; No 24/10/2010/NDCP, 2010). Regular on foot patrols focus on recording the extraction of timber, reduce poaching, avoid encroachment and restrict livestock grazing (Allendorf et al., 2007b), sometimes requires controlling illegal activity encounters. Thus, law enforcement practices by foot patrolling are commonly the approach to prohibit illegitimate activities in NRs, although the efficiency of such patrolling actions has often been questioned (Mukul et al., 2014). The following patrolling activity, the conventional styles of stable patrol routes on foot is applied and recorded by Global Positing System (GPS)-based monitoring (Jachmann, 2008a, c; Gandiwa et al., 2014; Wiafe, 2016).

Few studies have informed increased law enforcement performance in response to a decline in illegal activities in the level of forest station in Asia and Vietnam protected areas (Jachmann, 2008a, c), due to stable patrol routes which have been typically applying for PAs. In addition to this, Gandiwa et al. (2014): and Wiafe (2016) presented the proportion of all illegal activity encounter were relatively high in man-days and distance covered in one PAs. Further, with respects to illegal activity distribution, lack of law enforcement patrolling have been combined to sink in biodiversity conservation as a result of the growth of illicit activities (Bassett, 2005; Ogutu et al., 2011). Even although, there are some forest stations which support and implement the regular patrol actions. However, relatively rare research on stable patrol efforts of forest station level have been conducted in effective conservation, thus it is still unknown or lacks sufficient law enforcement effort of permanent patrol routes to address the threats to conservation (Bleher et al., 2006). Equivocally, various inquiries of information on patrol effort are still blind under forest management without evaluation on sustainable forest management. Regularly, information on patrol routes is conducted and recorded in a productive manner and normal law enforcement performance on foot (Jachmann, 2008a, c; Gandiwa et al., 2014; Wiafe, 2016). Crucially, almost of information on dangerous conservation derive from patrolling routes have been commonly recorded by 
forest rangers (Jachmann, 2008a, c) or a supportive group of forest protection. It is openly significant for look into conservation activity based on two forest stations in the different nature reserves. Particularly, almost study have considered on patrolling in the long-term such as each quarter and year. Thus, in the short-term, there have not explored as filling as this research.

Due to analysis the overall effect of patrolling exercises (distance and/or hour) and illegal activity encounters between Hon Can and Nam Tien FSs during the research period, that are independent and dependent variables (Gandiwa et al., 2013). Hence, the purpose of the study is to (1) compare law enforcement ranger in both forest stations by getting to explore the circumstances if patrol performance commonly show-off, (2) compare overall relative illegal activity richness and diversity amongst two forest stations (Werner and Raffa, 2000), (3) analyze efficient patrol efforts for effective conservation on stable patrol system of both stations in NRs if rangers have been frequently implementing their patrolling routes. It is crucial to recognize the areas where illegal activities were presented and focused in the short-term period because of concentrated conservation and management efforts (Rica et al., 2017). Addition to this, there is different patrol ranger efforts in both sides if rangers have been continually patrolling in this way.

\section{Material and methods}

\section{Site description}

This study was conducted in both forest stations likely Hon Can and Nam Tien FSs in Xuan Lien and $\mathrm{Pu} \mathrm{Hu}$ NRs respectively. Both forest stations are the closest to each town and the most crowded fringe population in buffer zone. Moreover, both nature reserves are the biggest in PAs in Thanh Hoa province. In local and national level, it is well-known patrol ranger effort amongst nature reserves. The description of two study areas, including foresters and effective patrol time, have been summarily presented (Table 1).

Table 1. Summary of basic information on both study areas

\begin{tabular}{c|c|c|c|c|c|c|c}
\hline $\begin{array}{c}\text { Name of } \\
\text { stations }\end{array}$ & $\begin{array}{c}\text { Name of } \\
\text { NRs }\end{array}$ & $\begin{array}{c}\text { Number of } \\
\text { sub-areas }\end{array}$ & $\begin{array}{c}\text { Total } \\
\text { areas (ha) }\end{array}$ & $\begin{array}{c}\text { Forest } \\
\text { officers }\end{array}$ & $\begin{array}{c}\text { Effective patrol } \\
\text { staff/times }\end{array}$ & $\begin{array}{c}\text { Distance from } \\
\text { station (km) }\end{array}$ & $\begin{array}{c}\text { Average } \\
\text { Elevation (m) }\end{array}$ \\
\hline Nam Tien & Pu Hu & 6 & 2,900 & 2 & 8 & $0.9-10$ & $165-1,240$ \\
Hon Can & Xuan Lien & 4 & 2,400 & 4 & 6 & $0.1-6$ & $90-1,549$ \\
\hline
\end{tabular}

Specifically, Hon Can FS belongs to Xuan Lien NR located in Thuong Xuan district in Thanh Hoa province, in the northeast Vietnam, near the border with Nam Xuan biodiversity conservation area in neighboring Laos. And Xuan Lien NR covers an area of approximately 24,000 ha and is lied between latitude $19^{\circ} 52^{\prime}$ to $20^{\circ} 02^{\prime} \mathrm{N}$, longitude $104^{\circ} 58^{\prime}$ to $105^{\circ} 15^{\prime} \mathrm{E}$. Hon Can FS, among 5 forest stations, is the only one station controlling and patrolling 2,900 ha of the core-zone of the NRs (Table 1) and responsible for the law enforcement. The fully protected core-zone of Hon Can FS (the South of border NRs) is to consider on 355 households and 1,612 inhabitants in three adjacent villages in the buffer zones. Due to the high density in the buffer-zone, there is 
constant pressure on the protected area with illegal activities like logging, encroachment, poaching etc.

$\mathrm{Pu} \mathrm{Hu} \mathrm{NR}$ is located in two districts, such as Quan Hoa and Muong Lat in Thanh Hoa province, in the northeast Vietnam. It has a mountainous area of around 22,688 ha (latitude $20^{\circ} 30^{\prime}$ to $20^{\circ} 40^{\prime} \mathrm{N}$ and longitude $104^{\circ} 40^{\prime}$ to $105^{\circ} 05^{\prime} \mathrm{E}$ ). There are separately seven protected areas of which Nam Tien FS is one station controlling and patrolling 3,000 ha of the core-zone of the nature reserve. In the protected buffer zones, there have around 12 villages in Nam Tien and Thien Phu communities with 450 families and 1,200 habitats. Particularly, the local citizen living in and around NRs often influence the ability of the PA to meet conservation commission (Ormsby and Kaplin, 2005). Similar to the issue of Hon Can FS area, there have been hunting, cutting, and grazing.

\section{Data collection}

The study focused on research in the Hon Can and Nam Tien protection areas and data collected from May to August 2017 (Fig. 1). The survey following the main track was conducted by author and rangers which forest stations have been frequently patrolling as law enforcement practice, and noting any observations indicating nonpermitted actives caused by humans or livestock (Ormsby and Kaplin, 2005). The observation was once of both forest stations how to patrol and what to explore. A comparison of these patrol activities was pointed out the estimation of patrolling efficiency in both sides. During the working field, the location of illegal activity was left marks in the land, tree, stone, etc. Addition to this, an observation of hearing, feeling, and directed observation the landscape was recorded by using GPS device and standardized data sheet (Gray and Kalpers, 2005; Jachmann, 2008c; Wiafe, 2016). Such indicator of illegal activities could be location and direction marks by humans made with stones, sticks or marks on trees. Additionally, slip or drag-marks on the ground caused by tree trunks, bamboo, branches or hunted animals.

The primary observations of distinguishing marks and indicators of illegal activities were collected on such field trips and filed by local forest officers from both forest stations, sometimes Department of Science and International Cooperation and the Department of Law Enforcement of the Head-Office of both NRs as well as the Nature Protection Groups of the adjoining villages. The patrol tracks and coordinate-points (the longitude and latitude points of appearance of illegal activity (Jachmann, 2008a) from the GPS were tabulated with Microsoft Excel and transferred into MapInfo Software. Data for pressure and threat facing both forest stations were derived from an evaluation of protected areas patrol efforts effectiveness (Ayivor et al., 2013) which mainly carried out the forest rangers regularly. In order to avoid bias, author and the same rangers patrolled during the research. Even through, rangers have not been working the permanent location.

\section{Data analysis}

After collecting the data, descriptive statistics were designed to the summary of the characteristic of illegal activity found, and a Spearman's rank correlation among variables such as illegal activity found, patrol-hours, patrol's distance and man-patrolday (Jachmann, 2008c; Wiafe, 2016). The number of illegal activity found, and protection given by the government rangers between Hon Can and Nam Tien FSs were distinct among the patrolling tracks. Law enforcement efforts were simply analyzed the 
effective patrol-distance and man-day derived (Jachmann, 2008a, b) or special patrolhour as well (Wiafe, 2016). A non-parametric Mann-Whitney (U) test was used to compare the relative abundance of illegal activity found and other variable law enforcement efforts between the two forest station areas.
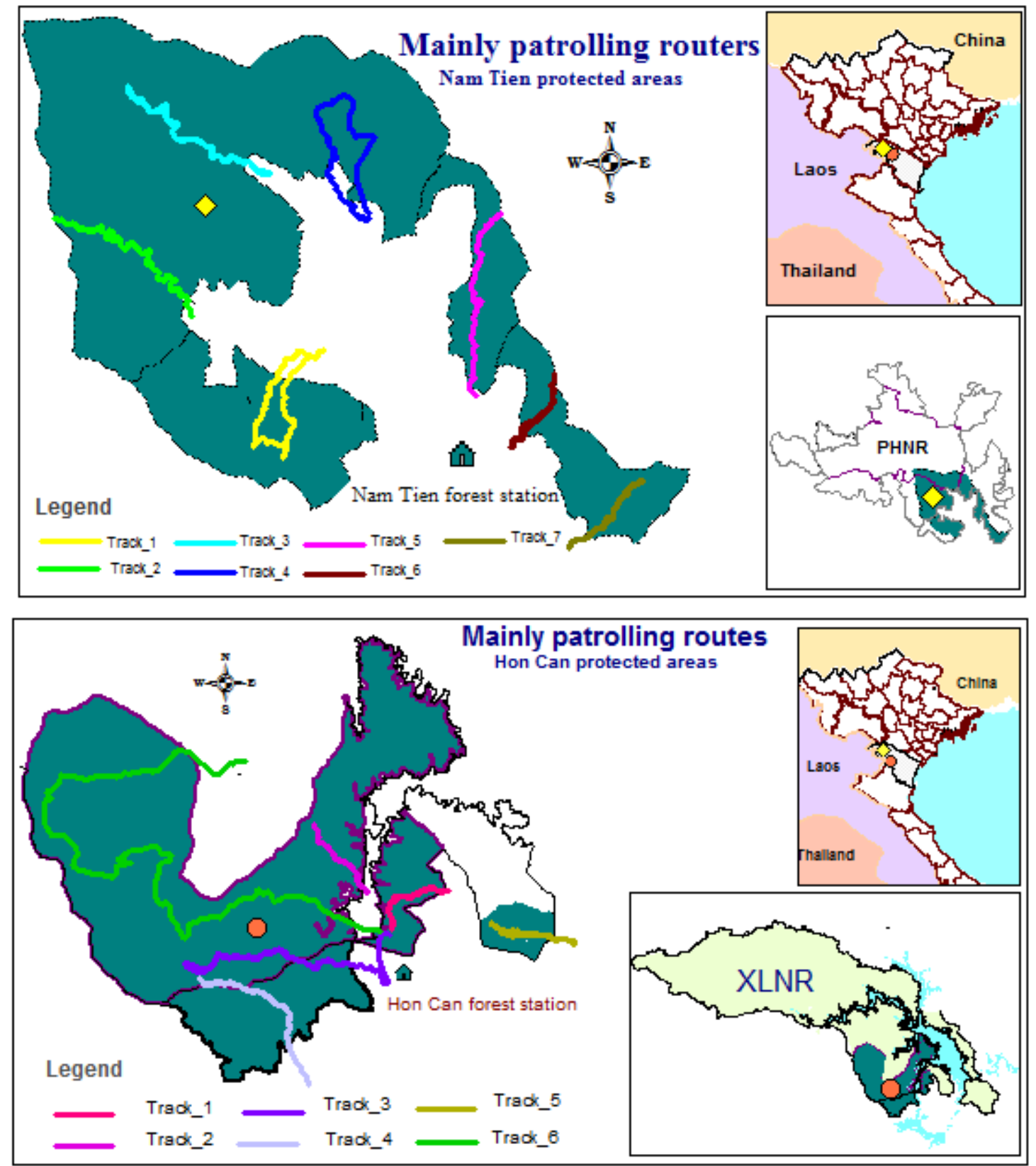

Figure 1. The location of both case study areas (2017)

\section{Results}

Totally, the findings from this study, following selected seven and six patrol-tracks, were normally patrolled on foot by forest officers of Hon Can and Nam Tien FSs respectively. Due to stable patrol-routes, almost patrolling tracks were thoroughly cross at least sub-areas of forest protection except for one track in Hon Can FS. These tracks 
were presented with different priorities, like distance, time consumption, foresters and illegal activity found in protected areas. As all patrol-routes in both forest stations can be displayed (Fig. 1).

\section{Staff's performance of patrolling}

The mean number of distance of patrol efforts was not significantly lower for Nam Tien FS (5.89 \pm 1.71$)$ compared to Hon Can FS $(6.17 \pm 3.02)(\mathrm{U}=23.5, \mathrm{p}=0.898)$. Similarly, the mean number of patrol-hours Nam Tien $(3.43 \pm 1.46)$ and Hon Can (4.84 \pm 4.09$)(\mathrm{U}=22.0, \mathrm{p}=0.749)$ as well. Furthermore, the trend of the proportion of illegal activity encounter and staffs in Nam Tien is slightly high to distance patrolled, in opposite to Hon Can. Due patrol-hour in both case studies, the trend of illegal activity found/staff improved more exponentially in Nam Tien than in Hon Can FSs (Fig. 2).

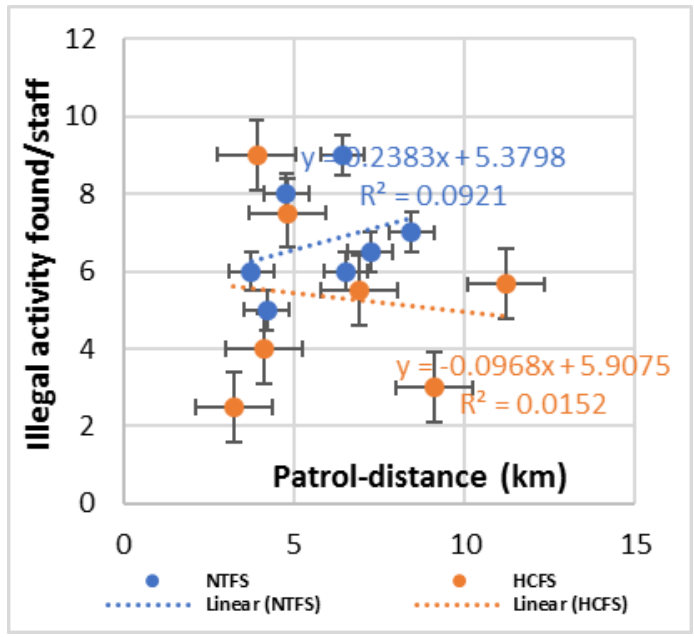

a

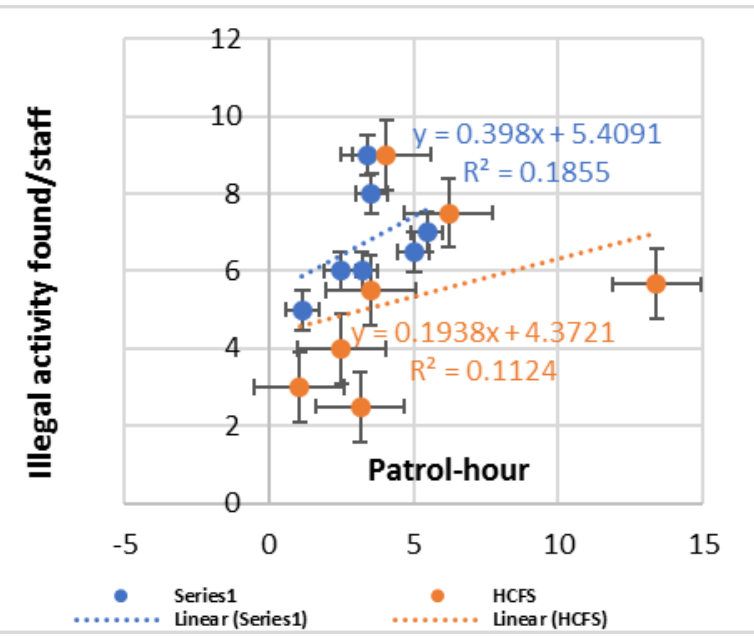

b

Figure 2. Trends of proportion of illegal activity encounter/staff in term of (a) patrol-distance and (b) patrol-hour

The number of forest officers were correlated with long routes in Nam Tien FS ( $r s=0.791, p=0.034)$, whilst Hon Can FS had different aspect $(r s=0.134, p=0.775)$. However, our results of patrol-hour was opposite to Wiafe (2016) report when the number of staffs were correlated in both sides [Nam Tien, $r s=0.791, p=0.034$; Hon Can ( $r s=0.802, p=0.03)]$. According to Jachmann (2008a), the relation between the number of staffs and illegal activity encounter was significantly correlated, and there was the similarity of Nam Tien ( $r s=0.679, \mathrm{p}=0.034$ ) and of Hon Can ( $\mathrm{rs}=0.802$, $\mathrm{p}=0.03)$.

\section{Differential illegal activity found}

A total of 61 and 71 illegal activity encounters were simultaneously captured in Nam Tien and Hon Can FSs respectively. The average illegal activity found was 8.71 $( \pm 3.546)$ Nam Tien and 10.14 ( \pm 4.488) Hon Can (Fig. 3). The number of livestock grazing was the most popular amongst illegal activity found arounds coordinated points in Nam Tien and Hon Can FSs (19 and 17 respectively). Some examples for illegal activity founds are presented (Fig. 4). Bird's nares (2 recording points) and transport 
timber ( 2 recording points) were only found in Hon Can FS. Gunshot's heard were higher in Hon Can FS (11 points) compared to Nam Tien FS (4 points). The number of illegal activity found in both stations were not significant $(U=59.5, p=0.974)$.

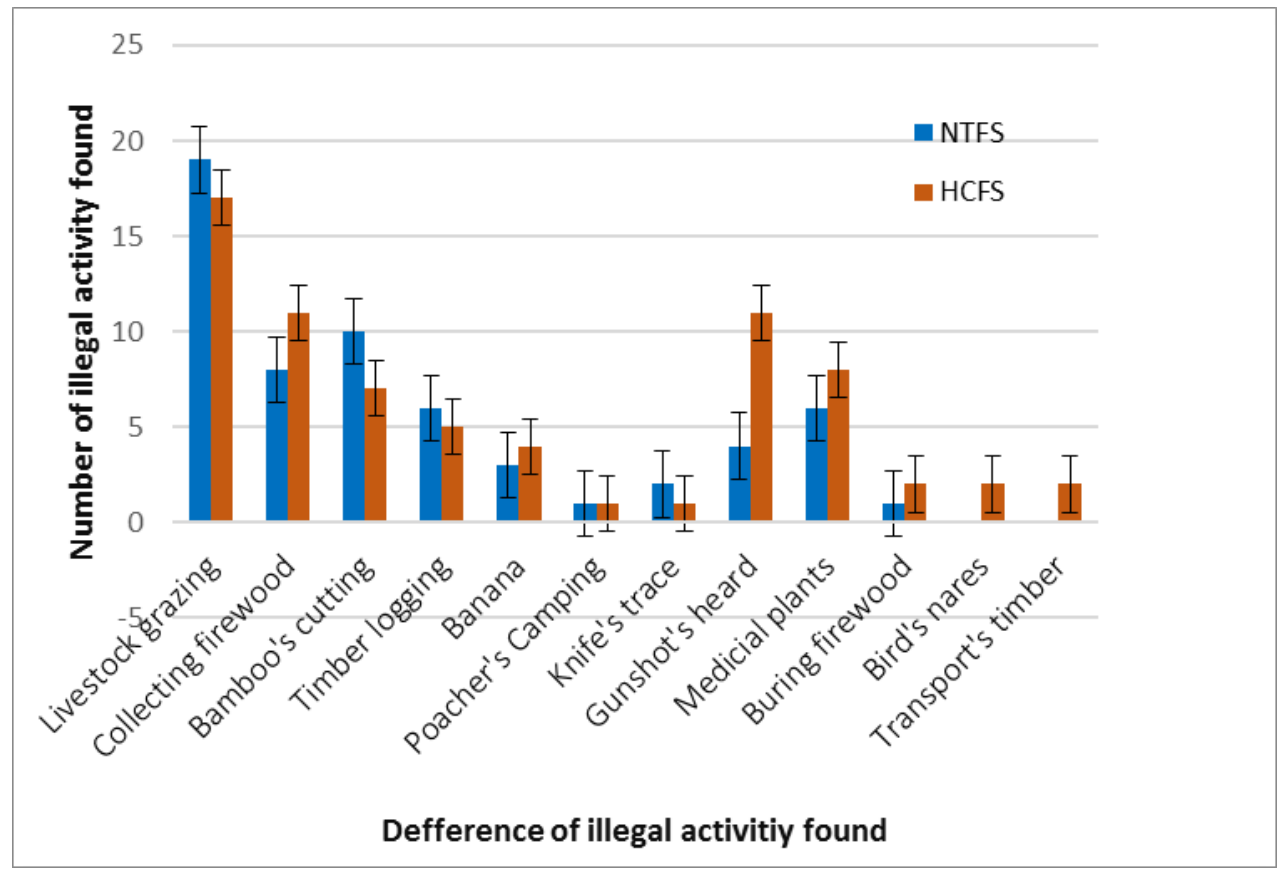

Figure 3. The diversity of encountered illegal activity

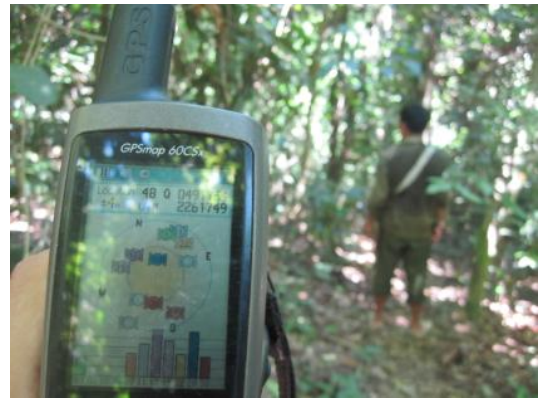

a

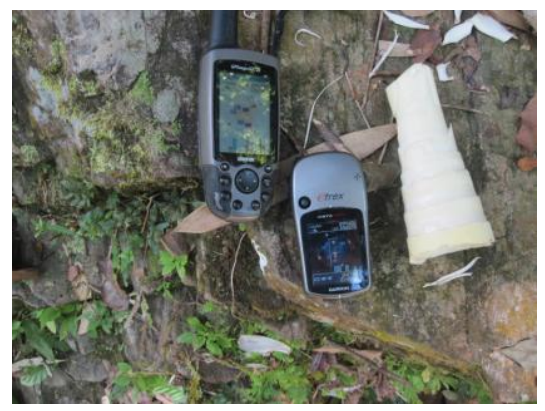

c

Nam Tien FS

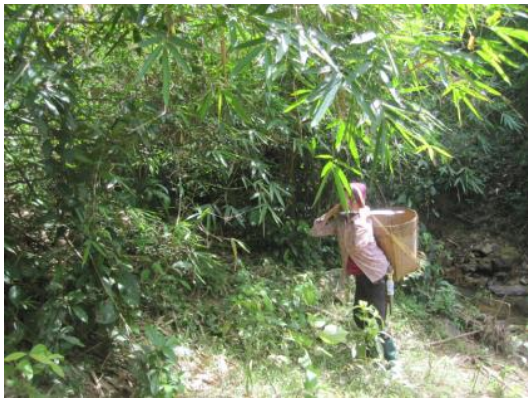

b

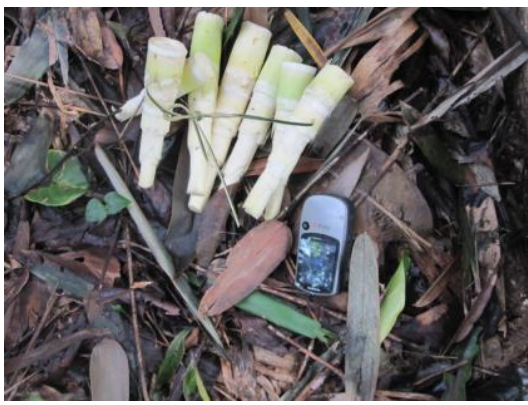

d

Hon Can FS

Figure 4. Human's illegal activity found both sides: $(a, b)$ Firewood collection; $(c, d)$ Bamboo collection, 2017 (by author, 2013) 


\section{Fluctuation of illegal activity found from law enforcement efforts}

This study showed that the longer patrol-distance and patrol-hour by forest officer in both stations have led to higher number of illegal activity found (Fig. 5). Seemly, law enforcement efforts were increased, and illegal activity found was increasing too. Specifically, the relationship between patrol-hour and illegal activity encounters was statistically significant [Nam Tien ( $\mathrm{rs}=0.955, \mathrm{p}=0.001$ ); Hon Can ( $\mathrm{rs}=0.857$; $\mathrm{p}=0.014)$ ]. Contrast to patrol-distance, it was correlated with illegal activity found in Nam Tien ( $\mathrm{rs}=0.793, \mathrm{p}=0.033$ ) while it was opposite to Hon Can ( $\mathrm{rs}=0.571$; $\mathrm{p}=0.18$ ). In this case of encountered illegal activity, it was evident that the patrol hour is more important than the distance of patrol routes.
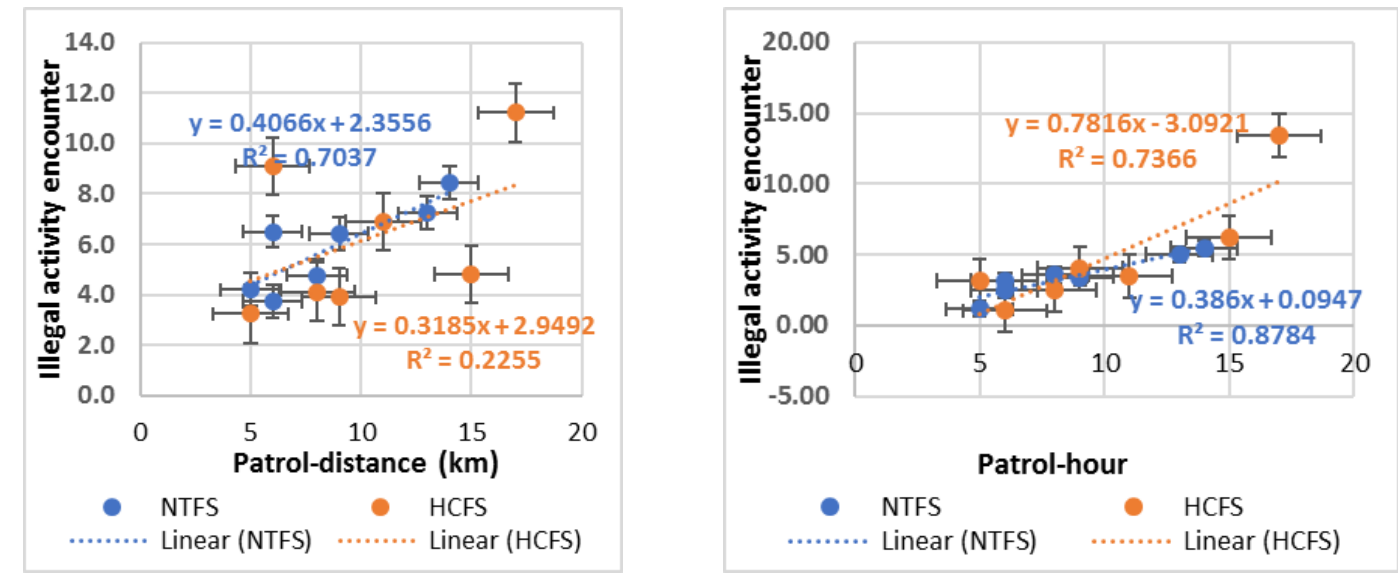

Figure 5. The tendency of illegal activity found in term of patrol-distance and patrol-hour

Interestingly, ratio of illegal activity found/patrol-distance, each case study, was not correlated to rate of illegal activity found/patrol-hour [Nam Tien FS ( $\mathrm{rs}=-0.214$, $\mathrm{p}=0.645$ ); Hon Can FS ( $\mathrm{rs}=-0.36 ; \mathrm{p}=0.939)$ ]. Furthermore, the relation of illegal activity found/patrol-distance and illegal activity found/patrol-hour, were not significant in both sides ( $U=19, p=0.482 ; U=22, p=0.749$ respectively). However, the trend of illegal activity found/patrol-distance was directly increased in Hon Can FS, compared to contrary to Nam Tien FS situation with slight decline (Fig. 6). Particularly, there was not different in both forest stations for illegal activity found in term of distance $(\mathrm{p}=0.52)$ and patrol-hour $(\mathrm{p}=0.482)$.

\section{Discussion}

\section{Patrol performance}

An understanding of the law enforcement that influence patrol effort can improve the forest management of natural resource (Abbot and Mace, 1999). Base on frequently patrolling routes of observation and prohibition of illegal activities sufficiently, the patrol effort by local rangers significantly depends on both distances and on the timeconsuming of each track. As a result, similarity to Jachmann (2008a) and Wiafe (2016) research, across all the patrol routes, due to distance patrolled and forest officers that were correlated in Nam Tien FS, in opposite to Hon Can FS as Risdianto et al. (2016) reported. Quite surprisingly, however, the patrol-hour in both was statically correlated 
with number staffs. It was undoubted that the number of staff in Hon Can is higher $100 \%$ than that is in Nam Tien, and implied that the few protection staff like Nam Tien FS lead to less opportunity to decline illegal activity (Jachmann, 2008c; Wiafe, 2016). According to Jachmann (2008a) and Wiafe (2016), they enabled to patrol for a long period. That was possible that manager might focus on the number of staff in Nam Tien FS instead of Hon Can FS somehow.

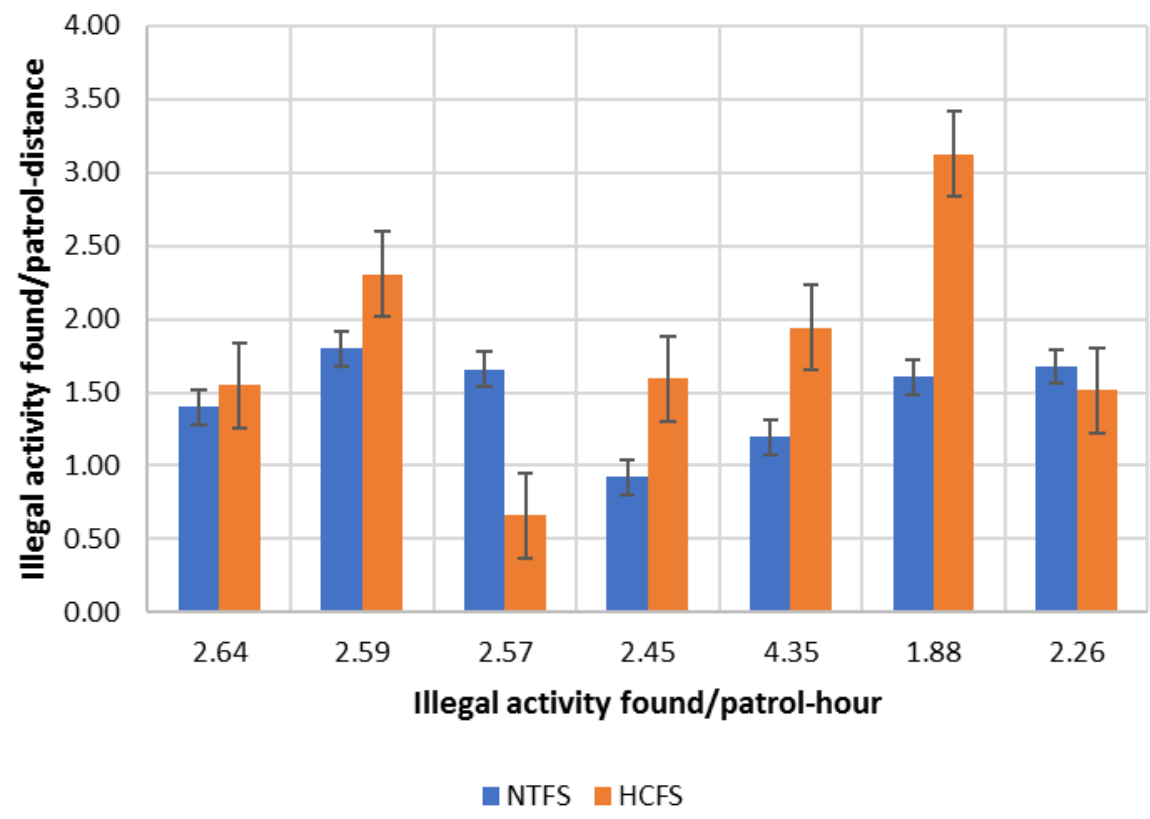

Figure 6. Trend of encounter rate of illegal activity found/patrolling distance and patrol-hour

Commonly, when the increasing number of staffs are similar to illegal activity found. Even though, there were certainly many influences of staffs to show off variable patrol (regarding distances and hours) or illegal activity found, however, it might hint that the protection staffs were the available indicator of patrol-hour and illegal activity explored. Actually, the patrol-hours from local rangers was depended on topography and several factors such as strict discipline of management characteristics, habit, serious issue of illegal activity found and senior staff efforts (Jachmann, 2008b). Based on buffer zone areas aspect, the cause given for illegal activities suggests that the economic, culture and unemployment should be accounted for the high consideration on patrolling in the richness of resources. Clearly, law enforcement may influence patterns of illegal activities in a comparison of two forest stations in different protected areas (Abbot and Mace, 1999).

\section{Illegal trend and patrol efforts}

It is undoubled that ecologic grazing always guaranteed adjacent community maintenance and it may lead to biodiversity conservation issues (Tichit et al., 2007) and influence to plant diversity (O'Connor et al., 2010). When comparing illegal activity encountered on stable patrol routes from both sides, mainly due to differences in visibility, there has been needed to distinguish between both FSs (Jachmann, 2008b). This is no surprise because this study showed that the longer patrol-distance and patrolhour by forest officer in both stations have led to higher number of illegal activity found 
in the long-term period (Fig. 5) (Jachmann, 2008a, c; Ayivor et al., 2013; Gandiwa et al., 2014; Wiafe, 2016). It denoted average trends of illegal activity encounters both in terms of patrol-distance and patrol-hour used for patrolling in the different tracks respectively. In both areas, upward trends of the ratio of illegal activity found in term of patrol-distance and patrol-hour in both sides were increasingly observed (Wiafe, 2016) (Fig. 5). As Plumptre et al (2014) represented that the current patrol effort based on distance did not deter illegal activities beyond in short-term evaluation.

Wiafe (2016) presented that there were many factors, e.g. the political plan, economy, and people's knowledge that converted the trend of contribution to illegal activity and law enforcement efforts to bring it down. Additionally, there are internal factors such as leadership styles, political management, logistics provide that might have an impact on field patrolling and other related operations (Jachmann, 2008c). External factors, e.g. topography, social, motivation, and educational level should also be considered. However, this research did not consider it because of the time constraint.

\section{Conclusion}

Effective law enforcement is crucial for conservation of our case study (Holmern et al., 2007). Overall, the finding from this study found out that the index of staff and patrol-time was an important part of law enforcement in conservation areas as for example of analysis of two forest stations above. The way of monitoring system presented in this research quickly provided useful feedback the local level of forest protection management (Jachmann, 2008b) without time-consuming of fieldwork in the large area. Further, during patrol effort implied to patrol-hour as the important quality of law enforcement performance of patrolling and it correlated with patrol-distance.

In the future, it is essential for the local level of management of the forest protection apply and compare the law enforcement practice among forest stations, due to the specific solution for excluding or at least minimizing these pressures and threat illegal activities (Mohseni, 2018) regarding the objectives of conservation. This research could be useful in the conventional law enforcement for observing the current situation and beginning the patrol planning strategy. However, it needs more thorough research about the law enforcement situation in the long-time period on both sides. The fluctuation of the amount of encountered illegal activity, in the similarity of patrolling routes, will be the subject of the forthcoming study. Addition to this, the strategies and planning from patrol staffs were freely altered, at any time, with regard to attaining patrol focuses but it relies on what the patrol forest officers have experienced and how the performance of patrol have been shown (Wiafe, 2016). Improving conservation is therefore essential for the conduct of law enforcement action from forest ranger that could be affected and supported protected areas.

Acknowledgements. We thank the Faculty of Environmental Management of Princes of Songkla University - Thailand for financing and supporting this research. Also, I appreciate the support of the forest rangers in Nam Tien and Hon Can forest stations as well as the Department of Law Enforcement and Department of Science and International Cooperation in both nature reserves for providing their technical services and cooperating to carry out the field research, being relevant advisers and sharing their experiences. Special thanks to supporting from Nature Protection Groups in adjacent villages for assistance during the field trips.

Conflict of interest. The authors definitely confirm that this article content has no conflict of interest. 


\section{REFERENCES}

[1] Abbot, J. I. O., Mace, R. (1999): Managing protected woodlands: Fuelwood collection and law enforcement in Lake Malawi National Park. - Conservation Biology 13(2): 418421. https://doi.org/10.1046/j.1523-1739.1999.013002418.x.

[2] Albers, H. J., Grinspoon, E. (1997): A comparison of the enforcement of access restrictions between Xishuangbanna Nature Reserve (China) and Khao Yai National Park (Thailand). - Environmental Conservation 24(4): 351-362. https://doi.org/10.1017/S0376892997000465.

[3] Allendorf, T. D., Smith, J. L. D., Anderson, D. H. (2007): Residents' perceptions of Royal Bardia National Park, Nepal. - Landscape and Urban Planning 82(1-2): 33-40. https://doi.org/10.1016/j.landurbplan.2007.01.015.

[4] Araújo, M. B. (2003): The coincidence of people and biodiversity in Europe. - Global Ecology and Biogeography 12(1): 5-12. https://doi.org/10.1046/j.1466822X.2003.00314.x.

[5] Arias, A. (2015): Understanding and managing compliance in the nature conservation context. - Journal of Environmental Management 153: 134-143. https://doi.org/10.1016/j.jenvman.2015.02.013.

[6] Ayivor, J. S., Gordon, C., Ntiamoa-Baidu, Y. (2013): Protected area management and livelihood conflicts in Ghana: A case study of Digya national park. - PARKS The International Journal of Protected Areas and Conservation 19(1): 37-47.

[7] Bach, C. E., Kelly, D., Hazlett, B. A. (2005): Forest edges benefit adults, but not seedlings, of the mistletoe Alepis flavida (Loranthaceae). - Journal of Ecology 93(1): 7986. https://doi.org/10.1111/j.1365-2745.2004.00961.x.

[8] Bassett, T. J. (2005): Card-carrying hunters, rural poverty, and wildlife decline in northern Côte d'Ivoire. - Geographical Journal 171(1): 24-35. https://doi.org/10.1111/j.1475-4959.2005.00147.x.

[9] Bleher, B., Uster, D., Bergsdorf, T. (2006): Assessment of threat status and management effectiveness in Kakamega Forest, Kenya. - Biodiversity and Conservation 15(4): 11591177. https://doi.org/10.1007/s10531-004-3509-3.

[10] Ciccarese, L., Mattsson, A., Pettenella, D. (2012): Ecosystem services from forest restoration: Thinking ahead. - New Forests 43(5-6): 543-560. https://doi.org/10.1007/s11056-012-9350-8.

[11] Clark, N. E., Boakes, E. H., McGowan, P. J. K., Mace, G. M., Fuller, R. A. (2013): Protected areas in South Asia have not prevented habitat loss: a study using historical models of land-use change. - PLoS ONE 8(5). https://doi.org/10.1371/journal.pone.0065298.

[12] Critchlow, R., Plumptre, A. J., Alidria, B., Nsubuga, M., Driciru, M., Rwetsiba, A., et al. (2016): Improving law-enforcement effectiveness and efficiency in protected areas using ranger-collected monitoring data. - Conservation Letters 0(0): 1-9. https://doi.org/10.1111/conl.12288.

[13] Fuentes, M. (2011): Economic growth and biodiversity. - Biodiversity and Conservation 20(14): 3453-3458. https://doi.org/10.1007/s10531-011-0132-y.

[14] Gandiwa, E., Heitkönig, I. M. A., Lokhorst, A. M., Prins, H. H. T., Leeuwis, C. (2013): Illegal hunting and law enforcement during a period of economic decline in Zimbabwe: A case study of northern Gonarezhou National Park and adjacent areas. - Journal for Nature Conservation 21(3): 133-142. https://doi.org/10.1016/j.jnc.2012.11.009.

[15] Gandiwa, E., Zisadza-Gandiwa, P., Mango, L., Jakarasi, J. (2014): Law enforcement staff perceptions of illegal hunting and wildlife conservation in Gonarezhou National Park, southeastern Zimbabwe. - Tropical Ecology 55(1): 119-127.

[16] Geldmann. J., M. Barnes, L. Coad, I. D. Craigie, M. Hockings, Burgess, N. D. (2013): Effectiveness of terrestrial protected areas in reducing habitat loss and population 
declines. $\quad-\quad$ Biological Conservation 161: 230-238. https://doi.org/10.1016/j.biocon.2013.02.018.

[17] Gray, M., Kalpers, J. (2005): Ranger based monitoring in the Virunga-Bwindi region of East-Central Africa: A simple data collection tool for park management. - Biodiversity and Conservation 14(11): 2723-2741. https://doi.org/10.1007/s10531-005-8406-x.

[18] He, G., Chen, X., Beaer, S., Colunga, M., Mertig, A., An, L., et al. (2009): Spatial and temporal patterns of fuelwood collection in Wolong Nature Reserve: Implications for panda conservation. - Landscape and Urban Planning 92(1): 1-9. https://doi.org/10.1016/j.landurbplan.2009.01.010.

[19] Holmern, T., Muya, J., Røskaft, E. (2007): Local law enforcement and illegal bushmeat hunting outside the Serengeti National Park, Tanzania. - Environmental Conservation 34(1): 55. https://doi.org/10.1017/S0376892907003712.

[20] Isbell, F., Calcagno, V., Hector, A., Connolly, J., Harpole, W. S., Reich, P. B., et al. (2011): High plant diversity is needed to maintain ecosystem services. - Nature 477(7363): 199-202. https://doi.org/10.1038/nature10282.

[21] Jachmann, H. (2008a). Illegal wildlife use and protected area management in Ghana. Biological Conservation 141(7): 1906-1918. https://doi.org/10.1016/j.biocon.2008.05.009.

[22] Jachmann, H. (2008b). Monitoring law-enforcement performance in nine protected areas in Ghana - Biological Conservation 141(1): 89-99. https://doi.org/10.1016/j.biocon.2007.09.012.

[23] Kusters, K., Belcher, B. (eds.) (2004): - Forest Products, Livelihoods and Conservation. Case Studies of Non-Timber Forest Product Systems (Vol. 1 - Asia). - CIFOR, Jakarta, Indonesia.

[24] Liang, J., Zhou, M., Verbyla, D. L., Zhang, L., Springsteen, A. L., Malone, T. (2011): Mapping forest dynamics under climate change: A matrix model. - Forest Ecology and Management 262(12): 2250-2262. https://doi.org/10.1016/j.foreco.2011.08.017.

[25] Mohseni, F. (2018): Identification of threat and pressure factors on protected areas using RAPPAM methodology (case study: Khuzestan Province, Iran) Applied Ecology and Environmental Research 16(1): 591-603.

[26] Mukul, S. A., Herbohn, J., Rashid, A. Z. M. M., Uddin, M. B. (2014): Comparing the effectiveness of forest law enforcement and economic incentives to prevent illegal logging in Bangladesh. - International Forestry Review 16(3): 363-375. https://doi.org/10.1505/146554814812572485.

[27] No 24/10/2010/ND-CP, C. Administration and management of special-use forest, Vietnam Goverment $\S \quad(2010)$ : Hanoi, Vietnam. http://moj.gov.vn/vbpq/lists/vn\%20bn\%20php\%20lut/view_detail.aspx ?itemid=26113.

[28] O'Connor, T. G., Kuyler, P., Kirkman, K. P., Corcoran, B. (2010): Which grazing management practices are most appropriate for maintaining biodiversity in South African grassland? - African Journal of Range and Forage Science 27(2): 67-76. https://doi.org/10.2989/10220119.2010.502646.

[29] Ogutu, J. O., Owen-Smith, N., Piepho, H. P., Said, M. Y. (2011): Continuing wildlife population declines and range contraction in the Mara region of Kenya during 1977-2009. - Journal of Zoology 285(2): 99-109. https://doi.org/10.1111/j.1469-7998.2011.00818.x.

[30] Ormsby, A., Kaplin, B. A. (2005): A framework for understanding community resident perceptions of Masoala National Park, Madagascar. - Environmental Conservation 32(2): 156. https://doi.org/10.1017/S0376892905002146.

[31] Patarkalashvili, T. (2016): Some problems of forest management of Georgia. - Annals of Agrarian Science 14(2): 108-113. https://doi.org/10.1016/j.aasci.2016.04.002.

[32] Plumptre, A. J., Fuller, R. A., Rwetsiba, A., Wanyama, F., Kujirakwinja, D., Driciru, M., et al. (2014): Efficiently targeting resources to deter illegal activities in protected areas. Journal of Applied Ecology 51(3): 714-725. https://doi.org/10.1111/1365-2664.12227. 
[33] Queiroz, J. S. de, Griswold, D., Tu, N. D., Hall, P. (2013): Vietnam Tropical Forest and Biodiversity Assessment. US Foreign Assistance Act, Section 118/119 Report August, 2013. - Sun Mountain International and the Cadmus Group, Inc., Quito, Ecuador.

[34] Rica, C., Gil-fernández, M., Sáenz, J., Carrillo-Jiménez, E., Wong, G. (2017): Distribution and hotspots of the feeding areas of jaguars on sea turtles at a national park in Costa Rica [Distribuição e pontos de concentração de áreas de predação de tartarugas]. - Neotropical Biology and Conservation 12(96): 2-11. https://doi.org/10.4013/nbc.2017.121.01.

[35] Risdianto, D., Martyr, D. J., Nugraha, R. T., Harihar, A., Wibisono, H. T., Haidir, I. A., et al. (2016): Examining the shifting patterns of poaching from a long-term law enforcement intervention in Sumatra $\quad-\quad$ Biological Conservation. https://doi.org/10.1016/j.biocon.2016.10.029.

[36] Rist, L., Moen, J. (2013): Sustainability in forest management and a new role for resilience thinking. - Forest Ecology and Management 310: 416-427. https://doi.org/10.1016/j.foreco.2013.08.033.

[37] Stevens, S. (1997): - Conservation through Cultural Survival: Indigenous Peoples and Protected Areas. - Island Press, Washington, DC.

[38] Stoll-Kleemann, S. (2010): Evaluation of management effectiveness in protected areas: Methodologies and results. - Basic and Applied Ecology 11(5): 377-382. https://doi.org/10.1016/j.baae.2010.06.004.

[39] Struhsaker, T. T. (1997): Ecology of an African Rain Forest: Logging in Kibale and the Conflict between Conservation and Exploitation. - University Press of Florida, Gainesville.

[40] Teich, M., Bebi, P. (2009): Evaluating the benefit of avalanche protection forest with GIS-based risk analyses-A case study in Switzerland. - Forest Ecology and Management 257(9): 1910-1919. https://doi.org/10.1016/j.foreco.2009.01.046.

[41] Thi, H. Do, Krott, M., Böcher, M. (2017): The success of scientific support for biodiversity conservation policy: The case of Ngoc Son Ngo Luong nature reserve in Vietnam. - Journal for Nature Conservation 38: 3-10. https://doi.org/10.1016/j.jnc.2017.05.002.

[42] Tichit, M., Doyen, L., Lemel, J. Y., Renault, O., Durant, D. (2007): A co-viability model of grazing and bird community management in farmland. - Ecological Modelling 206(34): 277-293. https://doi.org/10.1016/j.ecolmodel.2007.03.043.

[43] Werner, S. M., Raffa, K. F. (2000): Effects of forest management practices on the diversity of ground-occurring beetles in mixed northern hardwood forests of the Great Lakes Region. - Forest Ecology and Management 139(1-3): 135-155. https://doi.org/10.1016/S0378-1127(99)00341-2.

[44] Wiafe, E. D. (2016): Wildlife laws monitoring as an adaptive management tool in protected area management in Ghana: a case of Kakum Conservation Area. - Springer Plus 5(1): 1440. https://doi.org/10.1186/s40064-016-3129-x.

[45] Young, K. R. (2017): National park protection in relation to the ecological zonation of a neighboring human community: an example from northern Peru. - Mountain Research and Development 13: 267-280. http://dx.doi.org/10.2307/3673656.

[46] Zhou, M. (2015): Adapting sustainable forest management to climate policy uncertainty: A conceptual framework. - Forest Policy and Economics 59: 66-74. https://doi.org/10.1016/j.forpol.2015.05.013. 


\section{APPENDIX}

\section{In Hon Can station}

Firewood collection by local people

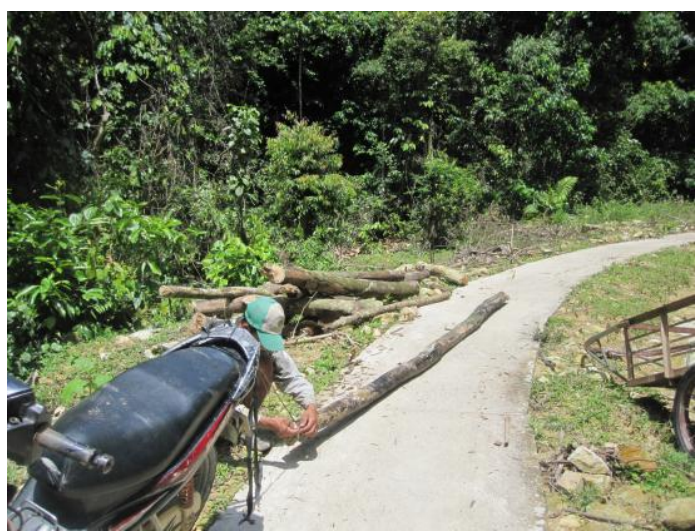

Collecting non-timber forest product

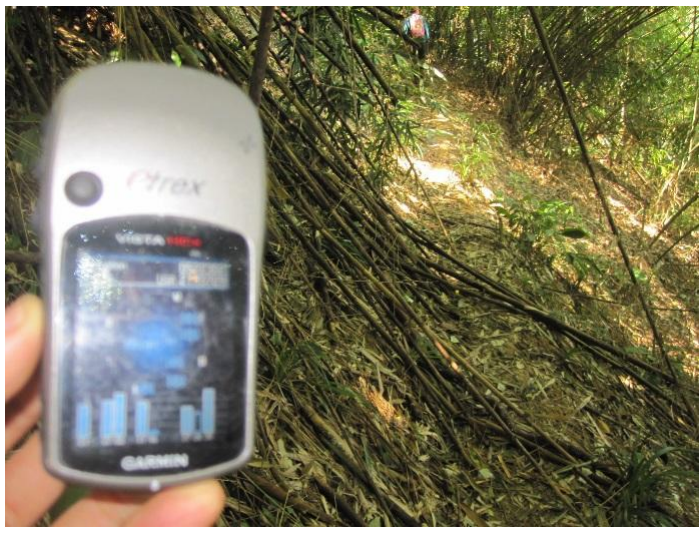

Bamboo's shoot harvesting

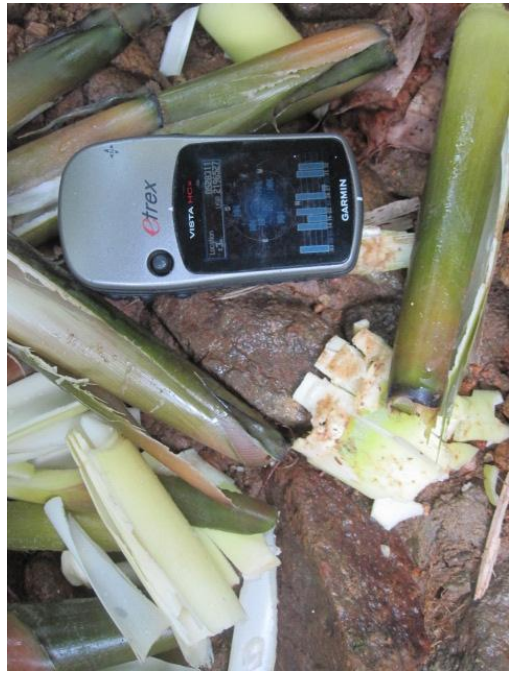

Cattle grazing in nature reserve

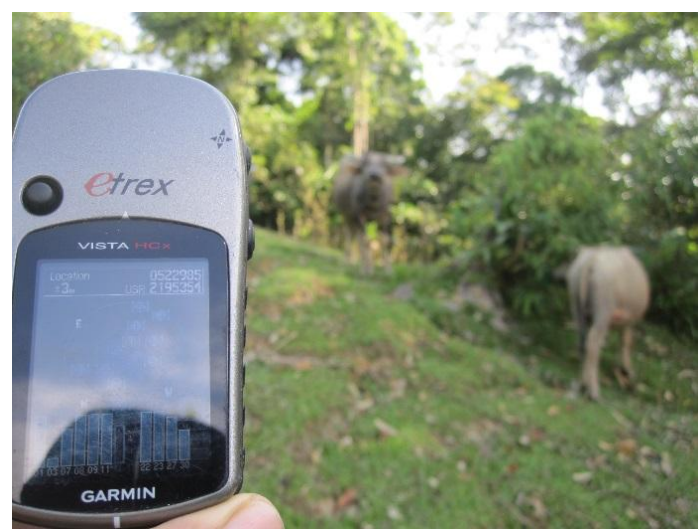

Banana leaf harvesting

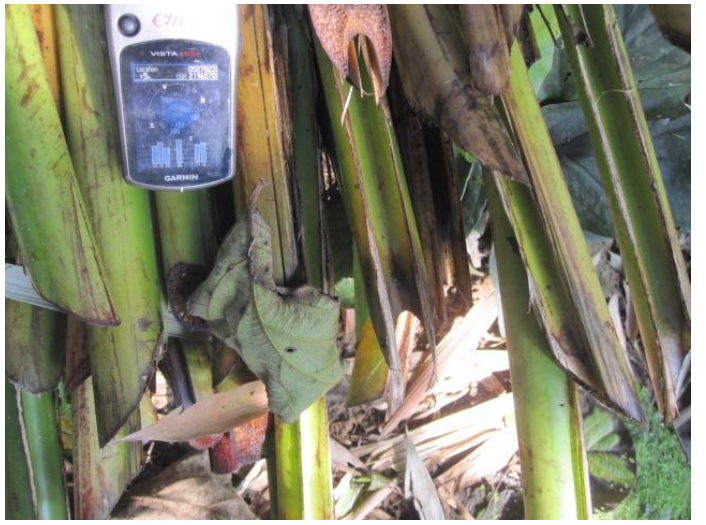

Bamboo harvesting

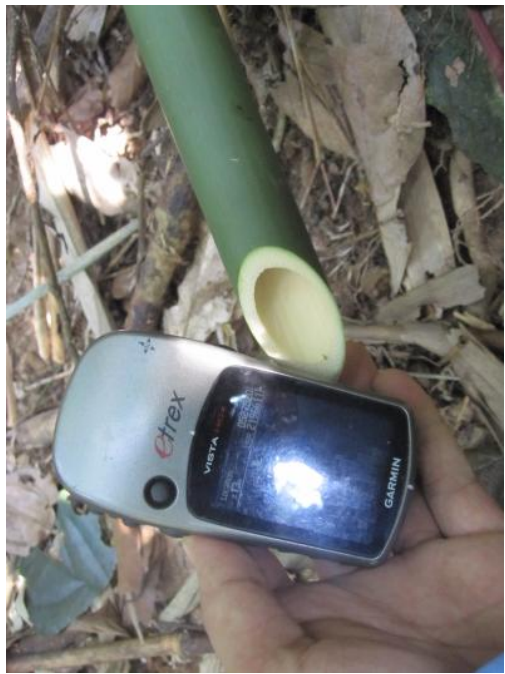




\section{In Nam Tien station}

\section{Bamboo harvesting}

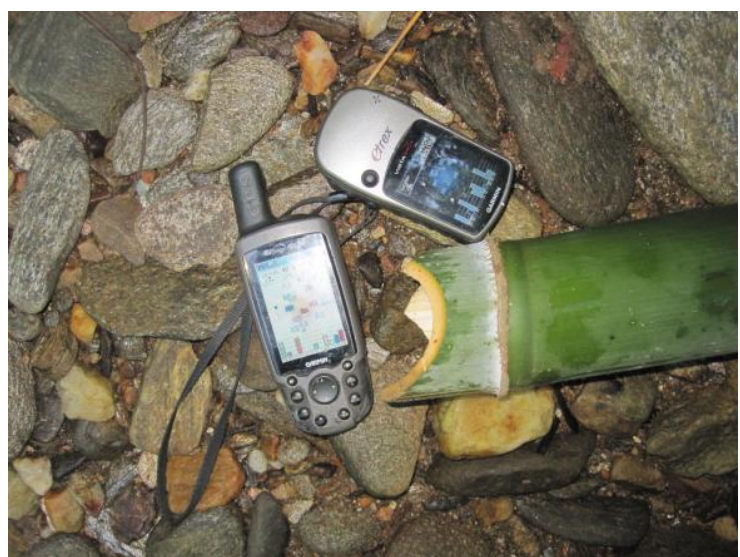

Bamboo shoot harvesting

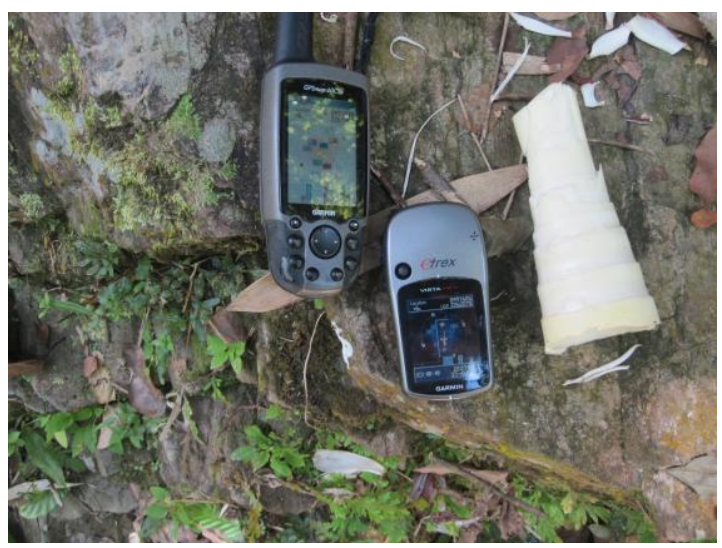

Camping hunter

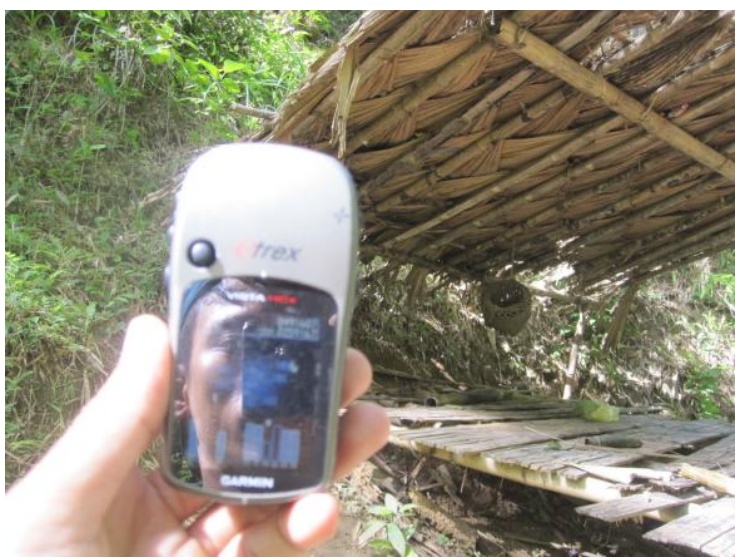

Basket of Bamboo shoot harvesting

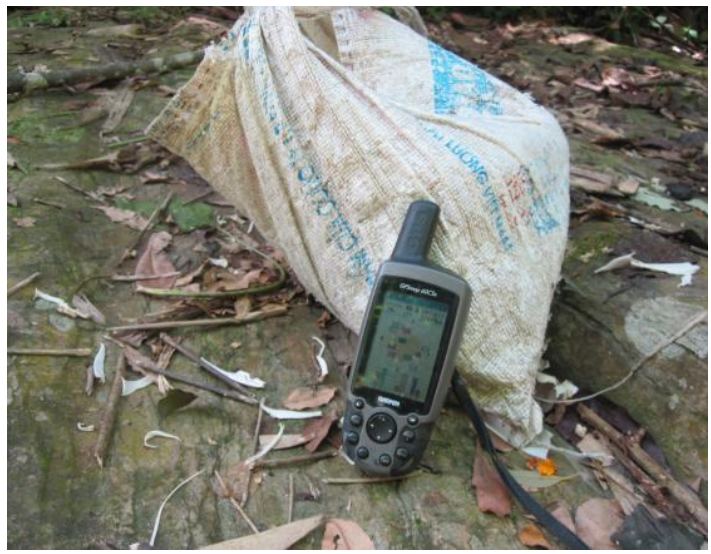

Thatch harvesting

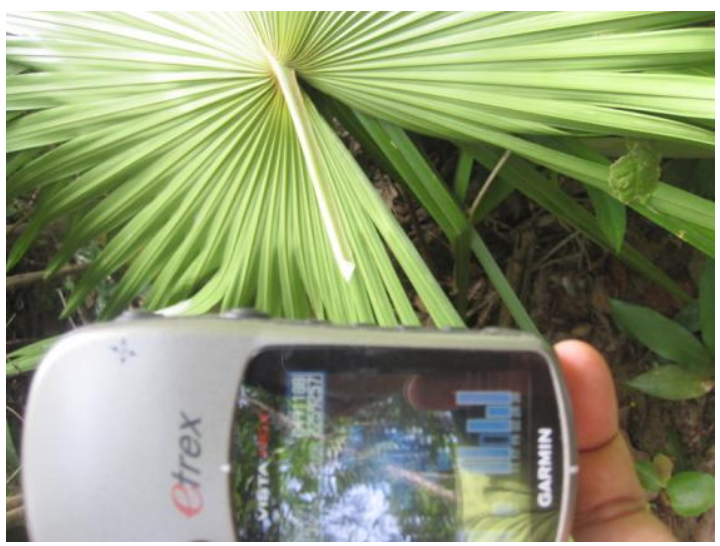

Bamboo harvesting

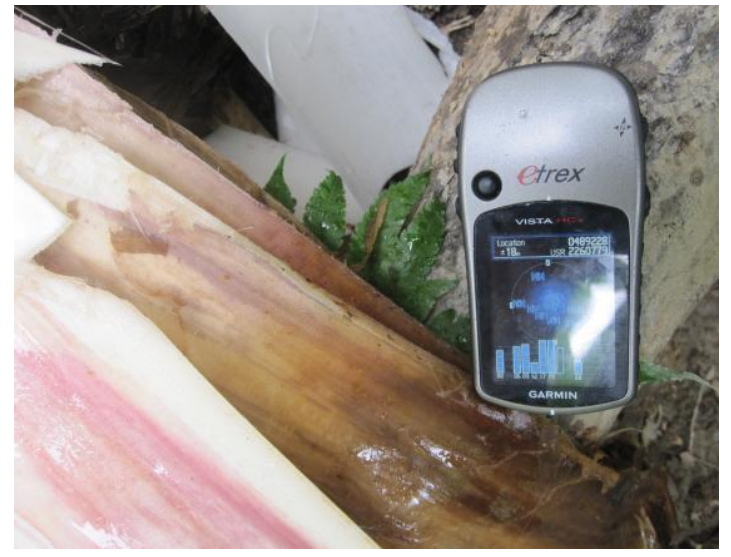

